\title{
THE EVOLUTION OF GHANA LAW SINCE INDEPENDENCE
}

\author{
William Burnett HarveY*
}

INTRODUCTION

On March 6, 1957, the British Gold Coast achieved independence in circumstances that apparently offered a bright future for sovereign, independent Ghana. Since r95I, adroit leaders of a well-organized political party had operated a responsible parliamentary government under British tutelage and reservations of power that was in fact never exercised. A growing body of African civil servants was supplemented at critical points by expatriate officers whose continued work in Ghana was assured by attractive economic arrangements. The national economy was prosperous, there was no encumbering debt, and the young government could plan national development fortified by large foreign exchange reserves. Independence was celebrated under a warm aura of goodwill toward the former colonial masters who in turn regarded the infant state as the vindication of decades of colonial administration in sub-Saharan Africa.

Since 1957, numerous other areas in Africa have achieved independence, but for many reasons Ghana has kept its position in the limelight. Its domestic problems, great and small, have occupied the world press which, unfortunately, has not always coupled its freedom to report with responsibility. On the international scene, Ghanaian activism has from time to time touched raw Cold War nerve ends, and Ghana like many of the new countries has felt the need of constant vigil to avoid becoming a mere pawn in the great East-West struggle.

Much of Ghana's post-independence development is of great interest, but this paper is limited to the evolution of its legal order. Before turning to the central subject, the hierarchy of norms comprising the law of Ghana, it will be helpful to sketch briefly the main course of constitutional development, emphasizing those aspects which relate most directly to the legal order in the narrower sense. Thus the legislative and executive establishments will be surveyed briefly, while the courts system will be described in somewhat greater detail. Since the functioning of any legal order is materially influenced by the professional lawyers, mention must also be made of the character and role of the bar.

\section{I}

\section{Constitutional Structure}

A. The Legislative Branch

On the granting of independence the legislative power of Ghana was vested in a Parliament of ro 4 members, 72 of whom were supporters of Dr. Kwame Nkrumah's

- A.B. I943, Wake Forest College; J.D. 1949, University of Michigan; Post Doctoral Fellow, University of Heidelberg, 1955-56. Professor of Law, University of Michigan. Dean of the Law Faculty, University of Ghana, and Director of Legal Education of Ghana. 
Convention People's Party. In general the institutional forms of the British parliamentary system were adopted. The written Constitution, ${ }^{1}$ however, imposed three substantive limitations on the legislative power of Parliament: (I) No law could "make persons of any racial community liable to disabilities to which persons of other such communities are not made liable."2 (2) Except for restrictions imposed for the preservation of public order, morality, or health, no law could "deprive any person of his freedom of conscience or the right freely to profess, practice or propagate any religion." (3) The taking of private property was subject to a right of adequate compensation, the amount to be judicially determined. ${ }^{4}$ In addition, the Constitution established certain procedural limitations on the exercise of legislative power, some involving the necessity for approval by regional organs. These special procedures applied to Acts altering regional boundaries and names of regions, ${ }^{5}$ affecting the status and functions of chiefs, ${ }^{6}$ or modifying the constitutional provisions of Ghana.? The various limitations, both substantive and procedural, were supported by a power of judicial review of legislation granted to the Supreme Court. ${ }^{8}$ The National Assembly, which was required to meet at least once a year, ${ }^{0}$ had a maximum life of five years. ${ }^{10}$

Between the Independence Constitution of 1957 and the Republican Constitution of 1960 , the most significant constitutional change affecting the legislative establishment was the repeal in $195^{8}$ of the provisions requiring special procedures for Acts revising the Constitution, altering regional boundaries, or affecting the chiefs. ${ }^{11}$ The three substantive limitations remained, but the National Assembly thus moved significantly toward full legislative sovereignty.

Following a national plebiscite in April $x 960$, when a tentative draft constitution was placed before the electorate, the Republic of Ghana came into existence on July I, 1960. The Republican Constitution articulates a theory of popular sovereignty ${ }^{12}$ which is directly reflected in the entrenchment of a number of provisions of the Constitution; entrenchment insulates them against change except after popular approval in a referendum ordered by the President. ${ }^{13}$ Aside from this entrenchment device, the legislative powers of Parliament are not limited. ${ }^{14}$ The three substantive safeguards of the 1957 Constitution survived only in a diluted form as part of a "solemn declaration before the people" which the President is required to make immediately after assuming office. ${ }^{15}$ The ultimate legislative competence of the

\footnotetext{
1 The Independence Constitution was promulgated as an Order in Council. [I957] I Stat. INSTR. 1036 (No. 277).

${ }^{2} I d . \S 3 I(2)$.

${ }^{8} I d . \$ 33$.

${ }^{8} I d . \S 3 I(5)$.

${ }^{3} I d . \$ 3 I(3)$.

Id. $\$ \$ 32(2)(3), 66-68$.

${ }^{\circ} \mathrm{Id} . \$ 46$.

${ }^{11}$ The Constitution (Repeal of Restrictions) Act, No. 38 of 1958.

12 Republican Const. art. I. ${ }^{13}$ Id. art. 20(2) and (4).

IId. $\$ 34$.

${ }^{7} I d . \$ 32$.

${ }^{10} \mathrm{Id} . \$ 47(2)$.

${ }^{15}$ Id. art. 13. The argument that the presidential declaration required by art. $\mathrm{r}_{3}(\mathrm{x})$ of the Constitution has juridical effect as a constitutional Bill of Rights limiting the legislative power of Parliament was rejected by the Supreme Court of Ghana in the Baffour Osei Akoto case, Civ. Appeal No. 42/6r, Aug. 28, 196r. Chief Justice Korsah, for the Court, said that the provisions of article ${ }_{3}(I)$ "are, in our view, similar to the Coronation Oath taken by the Queen of England during the Coronation Service. In the
} 
Assembly is curtailed, however, by the necessity for presidential assent before a bill can become effective, ${ }^{16}$ by the prohibition of amendments of the annual estimates (money bills) submitted by the Cabinet, ${ }^{17}$ and is at least qualified by the special legislative powers of the first President ${ }^{18}$ which will be mentioned later.

\section{B. The Executive}

In the conventional language of British constitutional law, the 1957 Independence Constitution vested executive power in the Queen, to "be exercised by the Queen or by the Governor-General as Her representative."19 The appointment of the GovernorGeneral $^{20}$ and the exercise of his powers were subject to the constitutional conventions applicable in the United Kingdom to the powers and functions of the Queen.12 Thus the executive power was actually wielded by a Cabinet headed by Dr. Nkrumah, responsible to the National Assembly. In general British practices were adopted; however, the constitutional document itself included a good bit of detail and in a few situations departed from the British model. ${ }^{22}$ This structure of the Executive was preserved until the advent of the Republic in 1960 .

The Republican Constitution conferred executive power on the President who is the Head of the State and Commander-in-Chief of the Armed Forces. The President is declared to be responsible to the people. ${ }^{23} \mathrm{He}$ is to be elected ${ }^{24}$ by the National Assembly acting as an electoral college, but the first presidential vote in the Assembly is automatically cast on the basis of preferences declared by members of the Assembly prior to their election. If no candidate receives a majority on the first ballot, members of the Assembly may vote their uncommitted preferences on subsequent ballots. If a President has not been elected on the completion of five ballots, the Assembly is deemed dissolved and new elections must be held with parliamentary candidates again declaring a binding presidential preference.

On election the President appoints his Cabinet who must be Members of Parliament though they are not responsible to Parliament. ${ }^{25}$ The President may at any

one case the President is required to make a solemn declaration, in the other the Queen is required to take a solemn oath. Neither the oath nor the declaration can be said to have a statutory effect of an enactment of Parliament. The suggestion that the declarations made by the President or assumption of office constitute a 'Bill of Rights' in the sense in which the expression is understood under the Constitution of the United States of America is therefore untenable."

${ }^{10}$ Republican Const. art. 24. ${ }^{17} I d$. art. $3 \mathrm{r}(2) . \quad{ }^{18} \mathrm{Id}$. art. 55.

${ }^{10}$ The Ghana (Constitution) Order in Council, [I957] I STat. INsTr. 1036 (No. 277), \$6.

20 The 1957 Constitution, $\S_{4}(\mathrm{I})$, merely vested the appointing power in the Queen. The British Government expressly recognized, however, that the Governor-General was to be appointed "in accordance with the conventions obtaining in other Commonwealth countries." The Proposed Constitution of Ghana, CMnd. No. 71, at 4 (1957). The convention contemplated appointment on the advice of the Ghana Government. See also 5 HalsBury's Laws of EnGLAND 448 (3d ed. 1953).

21 The Ghana (Constitution) Order in Council, [1957] I STAT. INSTR. I036 (No. 277), \$4.

${ }^{23}$ For cxample, $\$ 8(x)$ of the Constitution provided that the offices of the Ministers should become vacant whenever the office of Prime Minister became vacant and a new Prime Minister had been appointed.

${ }^{23}$ Republican Const. art. 8.

${ }^{24}$ Relevant provisions on the election of the President appear in article II of the Republican Constitution and in the Presidential Elections Act, Act. No. I of 1960.

${ }^{25}$ Republican Const. arts. 15, 16. 
time dissolve the Assembly. ${ }^{26}$ Thus if there should arise between the President and the Assembly differences of a kind that in a parliamentary system might produce a vote of no confidence or the breakdown of a really viable cooperation, the President is able to permit the people at any time to resolve the issues in a new general election. It should be noted, however, that restraint in dissolving the Assembly may be recommended by the fact that on dissolution a new presidential election must also be held, the President's term depending directly on the life of the Assembly. Should the President decline to dissolve the Assembly, no breakdown of cooperation, even to the extent of a direct expression of lack of confidence in the Executive, can force the President out of office. This fact may take on added significance in view of the special legislative powers of the first President, to be noted later.

Dr. Nkrumah was declared first President of Ghana. ${ }^{27}$ He was not elected by the processes described above but by a plebiscite conducted at the time the draft Republican Constitution was submitted to the people. In addition to the variety of executive powers conferred by the Constitution on any President, Dr. Nkrumah as first President was granted during his initial period in office the power to "give directions by legislative instrument." 28 The "initial period in office" is defined to mean "until some other person assumes office as President." Since an incumbent President is eligible for re-election any number of times, ${ }^{20} \mathrm{Dr}$. Nkrumah will enjoy the same legislative powers in any terms for which he is elected to succeed himself. Thus far, these special legislative powers of the President do not appear to have been exercised.

\section{The Court System}

A cardinal feature of the judicial order of Ghana, continued from its colonial past, is the division of judicial power between two systems of courts, one administering customary law of the bulk of the African population and the other applying British law or the recently developed national law to a much smaller European and African population. The evolution of both systems will be traced briefly. It should also be observed preliminarily that the judicial order has never appeared as a major point of controversy in the course of Ghana's constitutional evolution; post-independence developments have thus been able to proceed quietly, largely along lines projected from the colonial period.

At the date of independence, systems of Native Courts existed under separate legislation for the Colony, ${ }^{30}$ Ashanti, ${ }^{31}$ the Northern Territories, ${ }^{32}$ and Togoland ${ }^{33}$

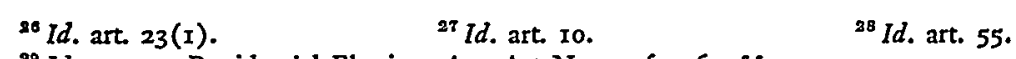

20 Id. art. xI; Presidential Elections Act, Act No. I of 1960, $\$ \$ 4-5$.

${ }^{30}$ Native Courts (Colony) Ordinance, No. 22 of 1944 , as amended, CAP. 98, LAws op the GoLd COAST (195I).

${ }_{21}$ Native Courts (Ashanti) Ordinance, No. 2 of 1935, as amended, Cap. 99, Laws of THE GoLD Const (I95I).

${ }^{89}$ Native Courts (North Territories) Ordinance, No. 31 of 1935, as amended, CAP. r04, LAws of THE Gold COAST (195I).

"Native Courts (Southern Section of Togoland) Ordinance, No. 8 of 1949, Cap. 106, Laws of maB Gold Const (195I). 
which together formed modern Ghana. Numerous relatively minor differences among the several systems will be ignored in this survey. The establishment of a Native Court and the authority of its members to sit depended upon the order of the colonial Governor and not upon chiefly status in the indigenous society. Such courts were, however, largely staffed by the chiefs and their counsellors. No special qualifications were demanded for appointment to a Court, but it was generally assumed that the members would be familiar with native law and custom in their own areas.

The jurisdiction of the Native Courts was defined in terms of both persons and subject matter. In general it may be said that jurisdiction over persons followed ethnic lines, including "persons of African descent" or "natives." It was possible for non-Africans to come within the jurisdiction of the Native Courts by voluntary submission or official direction, as well as for Africans to leave the jurisdiction by not following the "mode of life ... of the general community" or on a transactional basis by agreeing that British law should apply. Jurisdiction over subject matter was limited to civil claims under native customary law, certain customary offenses, causes arising under a few Ordinances and minor offenses under the Criminal Code. The Native Courts systems were related to the higher judicial order and the colonial administration by three basic control devices: (I) appeals to higher tribunals within the Native Courts system and in limited instances to an appeal tribunal outside the system; (2) transfers of cases from one Native Court to another or to a Magistrate's Court; and (3) review and revision of court action by District Commissioners or the Judicial Adviser. Professional lawyers were not permitted to practice before the Native Courts, but the charge was officially made that a group of "bush lawyers" actively practiced. ${ }^{34}$

The existing systems of Native Courts were unaffected by the grant of independence in 1957. A major attempt to revise the systems was made, however, in the Local Courts Act of $1958 . .^{35}$ The objective of the Act was a nationally uniform system of Local Courts without the hierarchy of grades formerly used. The substantive jurisdiction of the new courts was to be that of former Grade A Native Courts over minor civil cases and petty crimes, and the enforcement of a few Ordinances. An effort was made to eliminate the racial criterion for jurisdiction over persons which had applied in Native Courts. The change was largely formal, however, since the substantive jurisdiction continued to depend in the main on the application of customary law. The new Act also reflects an effort to maintain a higher quality of operation in the Local Courts through standards of efficiency for appointment as a court officer, courses of instruction, national supervision of arrangements of local government authorities for the courts, and the periodic inspection of court records. ${ }^{38}$ Administrative control over court operations was reduced, but control by

sc Native Trabunals Committee of Eneutry, Report 14 (Accra, I943).

The Local Courts Act, Act No. 23 of 1958.

${ }^{88}$ The Local Courts Act did not contemplate the immediate disestablishment of all Native Courts but rather their gradual replacement by Local Courts as personnel and facilities become available. The first Local Courts were not established until December 1959 when 23 Local Courts Magistrates were appointed 
appeals and transfers of causes continued to be exercised. The Local Courts system as described was preserved by the Courts Act of $1960^{37}$ which became effective on the advent of the Republic.

The higher judicial structure revised at the time of independence consisted of a Supreme Court, composed of the High Court of Justice and the Court of Appeal, ${ }^{38}$ and at the local level a system of Magistrates' Courts. ${ }^{30}$ The High Court of Justice was granted a wide range of original jurisdiction in major matters as well as appellate jurisdiction from Magistrates' Courts. ${ }^{40}$ The Court of Appeal was granted appellate powers in important cases from all lower courts, including Native Courts.1 It thus assumed jurisdiction over Gold Coast cases formerly enjoyed by the West African Court of Appeals, and appeal to that Court was abolished. ${ }^{42}$ Appeal from the Supreme Court of Ghana to the Judicial Committee of the Privy Council was retained $^{43}$ until the advent of the Republic in $1960 .{ }^{44}$ The tenure of Supreme Court Judges was protected by a constitutional provision for removal only on the address of the Assembly carried by not less than two-thirds of the membership, asking removal on the ground of stated misbehavior or infirmity of body or mind, ${ }^{45}$ and by a guarantee against diminution of salary during a judge's term of office. ${ }^{46}$ No such safeguards were provided, however, for judicial officers below the Supreme Court.

The Republican Constitution conferred the judicial power of Ghana on a Supreme Court and a High Court, designated the superior courts, and such inferior courts as might be created by law. ${ }^{47}$ The Courts Act of $1960^{48}$ contained very little innovation in its elaboration of the judicial structure. The Act was a consolidation of existing legislation with some modification of detail. Court names were somewhat changed, and a new system of Circuit Courts was introduced between the High Court and the District Courts. ${ }^{49}$ The power to appoint judges and judicial officers was somewhat more firmly concentrated in the President. ${ }^{50}$ The former safeguards

in the Eastern Region. On June 24, 1960, the remainder of the Native Courts were disestablished; $1 \times 4$ Local Courts Magistrates have been appointed, replacing about 170 former Native Courts. Thus far relatively little progress has been made in establishing training programs for Magistrates and other court officers, though Mr. John Jackson, the Senior Local Courts Adviser, is pressing efforts toward that end.

${ }^{37}$ Courts Act, 1960, C. A. 9. All enactments of the Constituent Assembly are separately numbered.

${ }^{38}$ The Courts (Amendment) Ordinance, No. 17 of $1957, \$ 2$.

${ }^{30}$ Courts Ordinance, No. 7 of 1935 , as amended, Cap. 4, LAws of the Gold Const (I951).

10 The Courts (Amendment) Ordinance, No. 17 of $1957, \$ 9$.

11 The Court of Appeal Ordinance, No. 35 of 1957.

${ }^{12} I d$. $\$ 23$.

$\$ 3$ The Ghana (Appeal to Privy Council) Order in Council, [1957] I STAт. INsTr. I197 (No. 136r).

14 Republican Consr. art. 42(I). By agreement between the Government of the United Kingdom and the Government of Ghana, appeals registered in the Privy Council office before the date on which Ghana became a Republic would be heard. Exchange of Letters, CMND. No. I190 (I960).

${ }^{45}$ The Ghana (Constitution) Order in Council, [1957] I STAT. INSTR. I036 (No. 277), 54 (3).

${ }^{10} I d . \$ 54(7)$.

17 Republican Const. art. 4I.

18 Courts Act, I96o, C. A. 9 .

${ }^{10}$ By Legislative Instrument 45 of 1960 , the Chief Justice divided the country into seven circuits, each circuit being composed of one of the Regions as defined in the Regions of Ghana Act, 196o, C. A. II, except that the Northern and Upper Regions were combined into one circuit.

${ }^{50}$ Republican Const. art. 45(I); Judicial Service Act, 1960, C. A. 10, 87. 
of tenure and salary were preserved for judges of the Supreme Court and High Court but were not extended further through the judicial system. ${ }^{51}$

\section{The Bar}

In its resources of legal talent Ghana is more fortunate than many of the new African states. Precise figures are not available, but it appears that about 350 lawyers are now authorized to practice in Ghana. Virtually all were qualified in England as barristers or solicitors, but recently a program for local qualification has been instituted. 52 Lawyers at the Ghana bar may practice as both barrister and solicitor, though certain requirements of practical training are imposed for a license to practice in the latter capacity. ${ }^{53}$

\section{The Hierarchy of Legal Norms}

The legal order in Ghana is pluralistic, encompassing not merely law derived from the former colonial power, now supplemented by post-independence legislation, and a system of courts to apply that law, but also a body of indigenous or customary law applied mainly in the Native, now Local, Courts. To avoid chaos some scheme was necessary to delimit the sphere of operation of each body of law and each system of courts and, in so far as these spheres coincided or conflicted, to determine which should prevail.

\section{A. Horizontal and Vertical Ordering}

Two basic methods for interrelating the component elements in a pluralistic system may be distinguished. The first involves the definition of discrete substantive areas of operation for each element in the system, with each element entirely uncontrolled by the other so long as it remains within its assigned area. Thus, for example, it is conceivable that the definition of major crimes such as murder, rape, and robbery might be made the function of English law or a nationally legislated norm and the application of that law assigned to a system of superior courts, while all other interpersonal relations of which the law took account were left entirely to a body or bodies of customary law applied in courts established by the indigenous regimes. Such a division of function between two systems may be referred to as involving horizontal ordering.

The other type of order is hierarchical or vertical. In this type the bodies of law and the applying courts are related as superiors and inferiors. While hierarchical ordering may permit some horizontal division of functions at least in the early stages of law application, it allows ultimate resort to the higher courts applying the superior or ultimately governing body of law in an appeal or some other type of supervisory proceeding. While such a distinction of types of relations is useful for

¿1 Republican Const. arts. 45(3), 46(r).

${ }^{52}$ Legal Profession Act, Act 32 of $1960, \$ \$ 13-15$.

${ }^{2}$ Id. $\$ \S 2,8$. 
some analyses, ${ }^{54}$ it would appear that in every pluralistic system there is an irreducible minimum of hierarchical or vertical ordering, since some overriding set of norms must at least define authoritatively the spheres of operation and application of the several bodies of law.

\section{B. The Courts Ordinance, I935}

The general standards defining the relations between English-derived law and native customary law in the pre-independence Gold Coast were found in the Courts Ordinance. ${ }^{55}$ It bears emphasis that these general standards were posited by the imperial power. Thus any ordering of the relations of English and indigenous law of the horizontal variety fitted into an overall hierarchical pattern dominated by imperial law. Both horizontal and hierarchical ordering were used, however, within that general structure.

The Courts Ordinance, section eighty-three, provided that "subject to the terms of this or any other Ordinance, the common law, the doctrines of equity, and the statutes of general application which were in force in England on the 24th day of July, I874, shall be in force within the jurisdiction of the Courts." The specified date derived its significance from the fact that the Gold Coast then acquired a local Legislature. English law made applicable in the Gold Coast by this section consisted of four elements: (I) local ordinances, (2) common law, (3) doctrines of equity, and (4) statutes of general application in force in England on the cut-off date. It is entirely clear, of course, that English statutes of general application that came into force after July 24, 1874 , were not per se applicable to the Gold Coast.

The question may be raised whether the same cut-off date applied to the common law and doctrines of equity, so that norms from these sources were applicable in the Gold Coast only as developed and articulated up to the cut-off date. The language of section eighty-three and the punctuation suggest that the cut-off date applies only to statutes of general application, thus making common law and equity doctrines as developed later by English courts also part of the Gold Coast law. Unless, however, one assumes an eternal completeness and immutability of common law and equity, these being merely discovered but not created by the courts, the same rationale underlying a cut-off date for statutes of general application would appear applicable to common law and equity as well.

Current acceptance of the view that courts do create law in the decision of cases on a common law or equity basis therefore suggests that English developments in these spheres after July 24, r874, were not applicable in the Gold Coast. This conclusion finds some support in section seventeen of the Courts Ordinance which provided that the Supreme Court of the Gold Coast should exercise its jurisdiction in probate, divorce, and matrimonial matters "in conformity with the law and

\footnotetext{
* For a useful application of this distinction to the international order, see Falk, International Jurisdiction: Horizontal and Vertical Conceptions of Legal Order, 32 TEMP. L.Q. 295 (1959).

${ }^{85}$ Courts Ordinance, No. 7 of 1935 as amended, CAP. 4, LAws of THE GoLd COAST (I95I), 55 83-89.
} 
practice for the time being in force in England." Evidently the draftsmen of the Ordinance were entirely competent to find language appropriate to an intention that the law in the Gold Coast should be continuously related to the current state of the law in England. It is thus arguable that the cut-off date in section eighty-three applied not only to statutes of general application but to common law and equity as well. This question was never authoritatively settled, however, while the Courts Ordinance remained in force. ${ }^{56}$

A further contribution of English law to the legal order of the Gold Coast consisted of "imperial laws declared to extend or apply to the jurisdiction of the Courts" (section eighty-five). Such laws were to apply only within the limits of local jurisdiction and to the extent local circumstances permitted. These relatively vague criteria necessitated more precise definition by judicial decision of the applicability of imperial laws. Similarly, courts in the Gold Coast were authorized to construe imperial laws with such alterations not affecting the substance of the enactment as would facilitate their application.

To handle cases of conflict among the norms derived from English law, a distinct hierarchy was required. Clearly, the paramount norms were those provided by imperial laws made expressly applicable to the Gold Coast or extended thereto by Orders in Council. Next in a descending order were those norms provided by local Gold Coast legislation. English statutes of general application in force in 1874 were received in the Gold Coast as legislation. Prevailing ideas of legislative supremacy would, of course, cause these statutes to prevail in cases of conflict with common law or equity doctrines. In the final cases of conflict between law and equity, which were concurrently administered in the superior courts of the Gold Coast, the rules of equity were to prevail (section eighty-six).

This hierarchical order of English norms co-existed with a number of bodies of customary law ${ }^{57}$ in force in various parts of the Gold Coast. Standards determining the relation of customary law to English law in a horizontal order were provided by section eighty-seven of the Courts Ordinance. Primarily these standards were ethnic. In causes or matters the parties to which were "natives," the primary law presumptively applicable was customary law. A party could, however, lose the benefit of customary law if it appeared either from an express contract or from

\footnotetext{
${ }^{50}$ The best available analysis of this problem and the related question of the extent to which English decisions were binding on Gold Coast Courts is Allott, The Authority of English Decisions in Colonial Courts, I J. Afrucan Law 23 (1957).

"77 The Courts Ordinance did not use the "customary law." It spoke rather of "native law or custom" and "local law or custom." Neither of these terms, which do not seem to differ in substantive meaning, was defined in the Ordinance. However, the Native Courts (Colony) Ordinance, No. 22 of I944 as amended, CAp. 98, LAws OF THE GoLd COAST (I95I), §2, defines "native customary law" as "a rule or body of rules regulating rights and imposing correlative duties, being a rule or body of rules which obtains and is fortified by established native usage and which is appropriate and applicable to any particular cause, action, suit, matter, dispute, issue or question, and includes also any native customary law recorded or modified in accordance with the provisions of sections 30 and 31 respectively of the Native Authority (Colony) Ordinance, r944." The procedure for the declaration or modification of customary laws by the traditional authorities will be discussed later.
} 
the nature of the transaction out of which the question arose that the party had agreed to have his obligations regulated exclusively by English law. If the parties to the cause or transaction included both natives and non-natives, English law was presumably controlling. Even in such a case, however, the courts were authorized to apply customary law if they determined that "substantial injustice would be done to either party by a strict adherence to the rules of English law."

Overriding this horizontal relation of English and customary law based on ethnic criteria was a hierarchical relation of customary law to certain limiting principles. Not all native law and custom existing in the Gold Coast was retained, but only such as was not "repugnant to natural justice, equity and good conscience" and not "incompatible either directly or by necessary implication with any ordinance for the time being in force." 58 Determinations of repugnancy or incompatibility were to be made by the courts.

In the main, the courts which actually invoked these limiting criteria were the superior courts, staffed principally by English personnel, though it was possible for a Native Court to exclude customary law on such grounds. ${ }^{50}$ Clearly in the case of incompatibility with any Ordinance, the standard invalidating the customary law was supplied by the colonial power. The "brooding omnipresence" of English law was further strengthened by the overriding standards of "natural justice, equity and good conscience" which impliedly were incorporated in English law or were at least revealed to the eyes of English judges. The same basis for decision was provided for any case within the jurisdiction of the Native Courts to which no express rule of the customary law was applicable. ${ }^{60}$

This pluralistic system created an appalling number of problems, most of which were neither clearly nor satisfactorily solved prior to the repeal of the Courts Ordinance. These difficulties need only be touched upon here. A serious issue was posed by the doctrine of precedent or stare decisis whereby the decisions of higher courts are binding on lower courts in the hierarchy. In applying this doctrine much uncertainty existed as to the binding effect on Gold Coast courts of decisions of the English High Court, the Court of Criminal Appeals, and the House of Lords. $^{61}$ We have already noted the question whether the cut-off date in section eighty-three of the Courts Ordinance applied to common law and equity as well as to English statutes of general application. There were also difficulties related to the

${ }^{88}$ Courts Ordinance, supra note 57 , at $\$ 87(\mathrm{r})$.

${ }^{50}$ Matson, Internal Conflicts of Laws in the Gold Coast, I6 MODERN L. REv. 469 (1953), indicates that the repugnancy standard has been used occasionally to deal with procedural irregularitics in native courts, but that the two principal categories of repugnancy cases are those involving slavery or practices analogized to slavery and cases involving disturbance of long-continued, bona fide possession of land.

${ }^{\circ 0}$ See Matson, supra note 59, at 475-76, for the suggestion that in certain types of cases betwcen natives, for example those involving the use of abusive or derogatory remarks, the courts have applied the English law of torts with "no pretence that that law is the embodiment of justice, equity and good conscience,' applied in the absence of any 'express rule' of customary law; they [the courts] do not consider the possibility that such a rule may exist."

${ }^{01}$ On this problem see Allott, supra note 56; Elias, Colonial Courts and the Doctrine of rudicial Precedent, 88 MODERN L. REv. 356 (1955). 
reception of such statutes themselves. What statutes fell within this category? Might parts of a statute be "of general application" and thus be applicable though other parts clearly were not? As a purely practical matter, how easily could a lawyer in the Gold Coast discover the English statutes in force in 1874 ? $^{62}$

The problems created by the application of customary law were probably even more difficult. Standards for solving the perplexing problem of excluding customary law in causes between natives on the basis of express or implied agreement that English law should govern were never adequately set out by the courts. When was such an agreement to be implied? ${ }^{63}$ When not all parties were natives, in what circumstances would the court's perception of injustice to one of the parties foreclose the application of English law and warrant resort to native law and custom? ${ }^{64}$

Perhaps most difficult of all was the matter of ascertaining the customary law in situations where the general hierarchy of norms indicated its applicability. The Courts Ordinance, section $87(2)$, provided that a court might "give effect to any book or manuscript recognized in the Gold Coast as a legal authority" and might "call to its assistance chiefs or other persons whom the Court considers to have special knowledge of native law and custom." The courts were also authorized (section eighty-nine) to refer questions of native law and custom to a competent Native Court for determination. Decisions of Native Courts on such referred questions were not appealable, but the referring court was in no way bound by them. The courts could accept or reject them, in whole or in part.

The methods for ascertaining customary law were entirely different in the superior or English courts and in the Native Courts. In the latter, customary law was assumed to be known to the members of the court who could apply it on the basis of their own knowledge, although a party relying on a particular custom was free to call witnesses to prove it. ${ }^{65}$ In the British courts, however, magistrates and judges could not be presumed to be familiar with the indigenous customary law; indeed, they were foreclosed from relying on such personal knowledge as their prior experience might provide. The party relying on customary law was therefore required to lay an adequate basis by allegation and proof for the court's application of customary law. The West African Court of Appeal held that "where a party intends to set up and rely upon a Native Law and Custom it must be specifically alleged and pleaded." ${ }^{\text {"66 }}$ This requirement was confirmed by court rules necessitating the pleading not merely of the substantive effect of the native law or custom but also the geographic area and the tribe or tribes to which it related. ${ }^{67}$

${ }^{02}$ See Atiyah, Commercial Law in Ghana, 1960 J. Business Law 430.

${ }^{\text {os }}$ For examples of judicial treatment of this problem, see Kwesi-Johnston v. Effie, I4 W.A.C.A. 254 (1953) and Ferguson v. Duncan, 14 W.A.C.A. 316 (1953).

" For cases in point see Koney v. Union Trading Co., Ltd., 2 W.A.C.A. I88 (1934); Nelson \& anor. v. Nelson \& othr., I3 W.A.C.A. 248 (I95I).

or Ababio II v. Nsemfoo, 12 W.A.C.A. 127 (1947).

${ }^{\circ 0}$ Bonsi v. Adjena II, 6 W.A.C.A. 24I (1940).

or Supreme Court (Civil Procedure) Rules, Ord. I9, $\mathrm{r}$ 3I 
Once adequate pleading opened the door, proof of the customary law itself remained difficult. By dictum in Angu v. Attah, the Privy Council declared that customary law "has to be proved in the first instance by calling witnesses acquainted with the native customs until the particular customs have, by frequent proof in the Courts, become so notorious that the Courts take judicial notice of them." ${ }^{88}$ The evidence contemplated by the first branch of this rule might come from chiefs, linguists, or others who could be qualified as experts on customary law. As mentioned earlier, the Courts Ordinance also permitted proof of customary law by the use of "any book or manuscript recognized in the Gold Coast as a legal authority" (section $87(2)$ ), and by reports from Native Courts on questions referred to them (section eighty-nine).

Incidentally it may be noted that use of textbooks or documents for the proof of customary law high-lighted a further complication. Such law was not uniform throughout the Gold Coast; on the contrary major differences existed between the principal cultural or tribal groups, and even within the same groups local variations were always a possibility. Thus even after a decision was reached that a cause was governed by customary law, the internal choice of law remained. Yet these complex problems were often overlooked by the courts. Particularly was this the case when customary law was proved by the use of textbooks. The most prominent of such works in the Gold Coast were the works of John M. Sarbah on Fanti law. ${ }^{00}$ The Fantis are a branch of the larger Akan group and are concentrated in the southwestern areas of the country. Sarbah had declared that "Fanti laws and customs apply to all Akans and Fantis, and to all persons whose mothers are of Akan or Fanti race."70 This seems a most doubtful generalization when one considers that the Ashanti are also Akans. Even the author made no pretension, however, that he described the laws of the Ga-Adangbe, Ewe, or other non-Akan peoples of the Gold Coast. Yet not infrequently the British courts accepted Sarbah's work as indicative of the applicable customary law between non-Fanti and even non-Akan parties. ${ }^{71}$

Determination of customary law as fact by the introduction of evidence is inconvenient and time-consuming as well as productive of uncertainty. The second branch of the dictum of Angu v. Attah suggested the possibility of dispensing with evidence when "the particular customs have, by frequent proof in the Courts, become so notorious that the Courts take judicial notice of them." Yet twenty-one years later, the Privy Council observed that "their Lordships have not been informed of any customary law so established; and they may observe that it would be very convenient if the Courts in West Africa in suitable cases would rule as to the native

\footnotetext{
${ }^{68}$ (1915) Gold Coast Privy Council Judgments, 1874-1928, at 43, 44. This dictum was later approved by the Judicial Committee in Amissah v. Krabah, 2 W.A.C.A. 30 (1936).

${ }^{\circ}$ John M. Sarbah, Fanti Customary Laws I6 (I897); John M. Sarbah, Fanti Law Report (1904).

70 John M. Sarbak, Fanti Customary Laws i6 (1897).

${ }^{7 x}$ See Matson, supra note 59 , at $478-8 \mathrm{r}$, for a review of relevant cases.
} 
customs of which they think it proper to take judicial notice, specifying, of course, the tribes (or districts) concerned and taking steps to see that these rulings are reported in a readily accessible form."72

While this method of establishing the content of the customary law has the advantages of convenience and certainty, it could also have the disadvantage of freezing the development of customary law, separating it from the on-going life of the community and in fact entirely changing the basis of its obligatory quality. In general, customary law is deemed binding because it reflects the consensus of the community as reflected in actual usage. When the custom becomes subject to judicial notice, however, it arguably derives its force not from usage but from the acceptance and implementation by the courts. If, as has been suggested, ${ }^{73}$ it was open to a party to show even after judicial recognition that a custom was no longer supported by established usage, much of the advantage of convenience and certainty attributable to judicial notice of oft-proved customary law would be lost. The admission of such proof would mean that judicial recognition of a custom had done little more than shift the burden of proof in a lawsuit.

Another device for establishing customary law without proof of usage was provided by legislation authorizing certain traditional authorities to make declarations of customary law or recommend its modification. An example of such legislation was the Native Law and Custom (Ashanti Confederacy Council) Ordinance of $1940,^{74}$ which authorized the Confederacy Council to declare what in its opinion was the native law and custom within the Confederacy relating to any subject. If the Governor in Council was satisfied that the declaration truly recorded the custom and was not repugnant to justice, equity or good conscience or incompatible with any Ordinance, he might declare it to be in force with the result that every court would be required to accept it as determinative of the customary law on the specified subject. The same Ordinance authorized the Confederacy Council to recommend modifications of native law and custom, which, subject to the same criteria, the Governor in Council might accept and implement. ${ }^{75}$ These powers have been negligibly used by the traditional authorities. It appears clear, however, that in so far as they are used, the law so declared ceases in fact to be customary

${ }^{72}$ Amissah v. Krabah, 2 W.A.C.A. 30, 3 I (1936).

${ }^{73}$ Allott, The ludicial Ascertainment of Customary Law in British Africa, 20 MODERN L. Rev. 244 (1957).

${ }^{72}$ Native Law and Custom (Ashanti Confederacy Council) Ordinance, No. 4 of 1940, CAP. I02, LAwS OF THE GOLD COAST (195I).

${ }^{75}$ Similar legislation for other divisions of the Gold Coast is the State Councils (Northern Territories) Ordinance, No. 4 of 1952, $\$$ 12, 13; the State Councils (Colony and Southern Togoland) Ordinance, No. 8 of 1952, $\$ 5$ 13, 14. The post-independence Houses of Chiefs Act, Act No. 20 of I958, $₹$ I $6(\mathrm{I})$, authorized a House of Chiefs to submit to the Governor-General or to the Speaker of the Assembly "a written declaration of what in its opinion is the customary law relating to any subject in force in any part of the area of its authority." The Act was silent, however, as to the status such a declaration would have in the courts or the functions it would perform for the legislative or executive branch. 
law and becomes a form of legislation, deriving its force like any positive law from being authoritatively laid down by official agencies. ${ }^{78}$

This brief sketch by no means exhausts the problems presented in administering the pluralistic legal order of the Gold Coast. Our purpose has been only to outline the various sources and kinds of legal norms and to indicate their relations in a general hierarchical and horizontal structure. It remains to consider the extent to which that structure has been modified in the post-independence legal order of Ghana, and to look briefly at the contribution which the changes may have made toward solution of the practical problems of administering justice.

\section{The Post-Independence Legal Order}

The hierarchy of legal norms was not greatly affected by the grant of independence on March 6, 1957. After that date, of course, the supreme position in the hierarchy was occupied by the constitutional Order in Council. Next came local legislation in the form of Acts of Parliament. No British statute enacted after independence extended to Ghana unless the Parliament of Ghana requested and consented to the enactment. Otherwise the pre-independence body of law was left intact. ${ }^{77}$ This basis structure of legal norms remained until the advent of the Republic on July I, I960, when the Republican Constitution and certain Acts of the Constituent Assembly made significant changes.

The basic statement on the new order of legal norms in Ghana is found in the Constitution, article forty, which provides:

Except as may be otherwise provided by an enactment made after the coming into operation of the Constitution, the laws of Ghana comprise the following-

(a) the Constitution,

(b) enactments made by or under the authority of the Parliament established by the Constitution,

(c) enactments other than the Constitution made by or under the authority of the Constituent Assembly,

(d) enactments in force immediately before the coming into operation of the Constitution,

(e) the common law, and

(f) customary law.

The constitutional list is suggestive of a hierarchical ordering but this is not made clear in the Constitution itself. For clarification of the new structure of norms we must turn to two enactments of the Constituent Assembly-the Interpretation $\mathrm{Act}^{78}$ and the Courts Act. ${ }^{79}$

The Interpretation Act of $I 960$ (section $I 7(I)$ ) provides that the common law received as part of the laws of Ghana includes, in addition to the rules generally known as the common law, the doctrines of equity and "rules of customary law included in

\footnotetext{
${ }^{76}$ For a full discussion of these problems see Allott, supra note 73 .

77 Ghana Independence Act, 1957, 5 \& 6 Eliz. 2, c. 6, §1.

${ }^{78}$ Interpretation Act, I960, C.A. 4. ${ }^{70}$ Courts Act, 1960, C.A. 9.
} 
the common law under any enactment providing for the assimilation of such rules of customary law as are suitable for general application." The effect of this provision for assimilation is not yet clear. A Ghanaian scholar has suggested that the assimilation device may "have been the sugar-coating which served to enable the drafters or their instructors to administer the common law pill to Ghana's lawmakers." The same author continues:

Short of legislative enactment by the national legislature, it is not easy to see how it can be left to the courts to decide which customary law rules to assimilate and generalize, and how communities subject to a different system of customary law of which they are equally proud are going to be induced to drop their own rule merely because the court has seen fit, in some particular case before it, to declare that a particular rule of customary law in one system is suitable for universal application and should be assimilated into the common law. This would seem to indicate that it would be preferable for the national legislature rather than the courts to tackle the general problem of customary law. ${ }^{80}$

It must be observed, however, that the Interpretation Act contemplated legislation on the subject of assimilation of customary law.

Basic implementing provisions were incorporated in the Chieftaincy Act of Ig6r. This statute commits the task of assimilating customary law into the common law not to the courts but to the Chiefs, the traditional rulers, subject to the ultimate discretion of the executive. On the initiative of either a Regional House of Chiefs or the Minister of Local Government, a joint committee drawn from the Houses of Chiefs of all the Regions may be convened to consider whether a customary law rule should be assimilated by the common law. If the joint committee favors assimilation, they may draft a declaration "with such modifications as they may consider desirable" for submission to the Minister. ${ }^{81}$ After consulting the Chief Justice, if the Minister is satisfied that effect should be given to the draft "either as submitted or with such modifications as he considers necessary," he may effect the assimilation by a legislative instrument. ${ }^{82}$ The resulting common law rule of customary origin has priority of application within its scope over other rules derived from the common law or any system of customary law. ${ }^{83}$ The Minister has discretion to devise transitional provisions relating to cases pending when the assimilation instrument is made. ${ }^{84}$

It is noteworthy that this assimilation scheme sanctions consciously legislative adjustments in the customary and common law. The Chiefs may recommend assimilation of an existing customary law rule or some modification. The Minister may decree the assimilation of the rule recommended by the Chiefs or modify it as he thinks necessary. Thus significant powers for effecting legal change are lodged in persons outside the conventional legislative and judicial structure. It does not appear, however, that these powers have been exercised up to this time.

\footnotetext{
${ }^{80}$ Bensi-Enchill, Ghana Faces Constitutional Problems, Harvard Law Record, Nov. 10, 1960, pp. 9, r3.

${ }^{81}$ Chieftaincy Act, $196 \mathrm{r}$, art. $81, \$ 62(2)$.

s. Id. $\$ 63(2)$.

${ }^{82}$ Id. $\$ 62(3)$.

${ }^{8}$ Id. $\$ 64$.
} 
The courts of Ghana inevitably have some leeway for creative activity in deciding cases not covered by statute. In so far as they draw inspiration for their decisions from some local custom, they may be said to have assimilated customary law into a body of national common law. This in fact is the historic method of the AngloAmerican common law and its use in the new order in Ghana may reasonably be expected. On the other hand, if the generalization of customary law is left to legislation or to the procedures outlined in the Chieftaincy Act, there seems to be little reason for categorizing the resulting rule as either common law or customary law; such a rule would derive its force from the enacting statute or legislative instrument. Determination of the significance of assimilation for legal change in Ghana must await developments.

The Courts Act of Ig60 repealed the old Courts Ordinance, but the common law, doctrines of equity, and statutes of general application in force in England on July 24,1874 , were retained. Section $I 7(I)$ of the new Interpretation Act defines the common law as including doctrines of equity and both were therefore retained in the new legal order of Ghana by article forty of the Republican Constitution. Statutes of general application were also retained, though somewhat circuitously. The Courts Act, section $154(4)$, kept in effect such statutes of general application in force in England on the cut-off date as applied in Ghana immediately before the Act became effective. Thus these statutes were preserved by the provision of article forty of the Constitution covering "enactments in force immediately before the coming into operation of the Constitution." The new Interpretation Act, section I7(3), further provides that these retained statutes of general application shall be treated as part of the common law and shall stand in the hierarchy of norms above any rule of the common law other than a rule assimilated from customary law.

The net result of this circumlocution is to preserve the statutes of general application in very nearly the same position relative to the common law which they occupied in the former hiercharcy of norms, except that now they are regarded as a preferred part of the common law.

A rule of equity, in case of inconsistency, is to prevail over any rule other than an assimilated rule. Thus it might appear that in the new hierarchy of norms equity doctrines have been raised above rules derived from English statutes of general application, if the latter are treated as part of the common law. On the other hand, the statute expressly states that rules derived from statutes of general application prevail over all other parts of the common law except rules assimilated from customary law. Since equity is defined as part of the common law, this suggests that statutes of general application have retained their precedence over equity doctrine. In this regard the provisions of section $I_{7}(2)$ and (3) of the new Interpretation Act may appear to present inconsistent views on the hierarchy of norms. A possible reconciliation might be effected by regarding the statutes of general application as technically not part of the common law as encompassed by section $x_{7}(\mathrm{I})$, and therefore deriving 
priority of application only from the specific rule of section $I_{7}$ (3) which ranks them above all common law rules except assimilated rules.

The enactments adopted on the creation of the Republic contain a novel set of provisions dealing with the administration by the courts of a common law system. As noted earlier, part of the English legacy to the Gold Coast was the doctrine of precedent or stare decisis. In the old order there was great uncertainty as to whether the decisions of certain English courts were binding on the courts of the Gold Coast and further over the effect of their dates on the status of English decisions, that is, the significance of their having been handed down before or after the date of the reception of English law in the Gold Coast. Some clarification on these points comes from the new Constitution. The appeal previously allowed from the courts of Ghana to the Judicial Committee of the Privy Council was eliminated; the Supreme Court of Ghana thus became the tribunal of last resort. ${ }^{85}$ Consequently after the establishment of the Republic no English court by its decision could bind the courts of Ghana. Within the hierarchy of Ghanaian courts the Constitution provides that ${ }^{88}$

The Supreme Court shall in principle be bound to follow its own previous decisions on questions of law, and the High Court shall be bound to follow previous decisions of the Supreme Court on such questions, but neither Court shall be otherwise bound to follow the previous decisions of any court on questions of law.

The Interpretation Act of 1960 further provides (section $\mathrm{I}_{7}(4)$ ) that "in deciding upon the existence or content of a rule of the common law, as so defined, the Court may have regard to any exposition of that rule by a court exercising jurisdiction in any country."

At first impression it appears that the Supreme Court of Ghana is constitutionally committed to a doctrine of precedent similar to that in England whereby the House of Lords is bound by its own prior decisions and therefore lacks the power, normally assumed by American courts, to correct its prior mistakes by overruling previous decisions either of common law or statutory interpretation. In England, the same doctrine of judicial restraint or impotence is often said to apply to the High Court with respect to its own prior decisions. To the extent that the doctrine has been accepted in Ghana, it seems to be limited to the Supreme Court.

A question may be raised, however, as to the significance of the provision that the Supreme Court shall be bound "in principle" to its prior decisions. In prevailing common law theory, the only binding aspect of a decision for later cases is its "principle" or ratio decidendi. Only by determining this principle can a court fix the authority, the binding aspect of a case. In the process of articulating the principle a court, therefore, has a range of flexibility and may succeed in distinguishing the present case so that it lies outside the authoritative principle. At least this much freedom is left to the Supreme Court of Ghana. Another possible interpretation of the constitutional provision, however, would equate the phrase "in principle" to "in

\footnotetext{
${ }^{86}$ Republican CoNst. art. 42(I).
}

${ }^{86}$ Id. art. $42(4)$. 
general" or "ordinarily." Such an interpretation would bring the doctrine of stare decisis in Ghana much more closely in line with that prevailing in the United States. Here the values of doctrinal stability and predictability of decisions are recognized and ordinarily are implemented. At the same time, however, these values may be sacrificed by judicial adaptation of the law to changed circumstances or by the correction of serious prior error. The pre-Republican constitutional discussions throw no light on this problem of interpretation, nor do decisions of the Supreme Court thus far.

In the pre-Republican legal order of the Gold Coast and Ghana, it was recognized that beyond the range of local and English decisions, binding under the accepted doctrine of precedent, lay a further range of English and Commonwealth decisions which might be recognized as highly persuasive. For example, in appropriate circumstances, decisions of the English High Court or House of Lords, of the East African Court of Appeal, or the Supreme Court of India might be accepted as correct declarations and applications of the law in force in Ghana as well. Despite their common legal roots, however, it is by no means common for courts in the English tradition to refer to American decisions. The possibility of greater resort to these resources is at least suggested by the Interpretation Act of $\mathrm{x} g 60$ which authorizes the courts of Ghana in deciding the existence or content of common law rules to "have regard to any exposition of that rule by a court exercising jurisdiction in any country." Whether this possibility will be realized can only be determined by observing the conduct of the courts of Ghana for the next several years.

Another interesting though probably academic question in the administration of Ghana's common law system concerns the power of the Supreme Court under the new dispensation to modify or abandon rules provided by the old English statutes of general application. As has been seen these are now categorized as part of the common law. Furthermore, such rules were not created by prior decisions of the Supreme Court and are not therefore protected by the stringent doctrines of precedent that one interpretation of the Constitution may have imposed on the Supreme Court. Arguably, therefore, the Supreme Court could modify them, as it might change rules forming part of the common law because laid down by prior decisions of the High Court or of English courts. This seems unlikely to occur to any considerable extent, however; such law reform will result if at all from legislation in Parliament.

The problem remains of determining the status of customary law in the new hierarchy of norms. As we have seen, the former Courts Ordinance made customary law applicable in causes between natives unless an agreement could be found to have English law apply, and in causes between natives and non-natives if the court should decide that injustice would result to either party from the strict application of English law. Understandably an effort has been made in the new legislation to abandon an avowedly ethnic criterion for determining the applicable legal 
rules and also to deal with the complex problems of conflict between bodies of customary law and of determining the content of customary law rules.

Standards for determining the choice between common law and customary law are provided by a series of rules in section sixty-six of the new Courts Act. The new organizing concept is that of "personal law" which is defined as the system of customary law to which a person is subject or, "if he is not shown to be subject to customary law ... the common law." The six rules must be quoted in full text:

Rule $x$. Where two persons have the same personal law one of them cannot, by dealing in a manner regulated by some other law with property in which the other has a present or expectant interest, alter or affect that interest to an extent which should not in the circumstances be open to him under his personal law.

Rule 2. Subject to Rule $I$, where an issue arises out of a transaction the parties to which have agreed, or may from the form or nature of the transaction be taken to have agreed, that such an issue should be determined according to the common law or any system of customary law effect should be given to the agreement.

In this rule "transaction" includes a marriage and an agreement or arrangement to marry.

Rule 3. Subject to Rule $\mathrm{r}$, where an issue arises out of any unilateral disposition and it appears from the form or nature of the disposition or otherwise that the person effecting the disposition intended that such an issue should be determined according to the common law or any system of customary law effect should be given to the intention.

Rule 4. Subject to the foregoing rules, where an issue relates to entitlement to land on the death of the owner or otherwise relates to title to land-

(a) if all the parties to the proceedings who claim to be entitled to the land or a right relating thereto trace their claims from one person who is subject to customary law, or from one family or other group of persons all subject to the same customary law, the issue should be determined according to that law;

(b) if the said parties trace their claims from different persons, or families or other groups of persons, who are all subject to the same customary law, the issue should be determined according to that law;

(c) in any other case, the issue should be determined according to the law of the place in which the land is situated.

Rule 5. Subject to Rules I and 3, where an issue relates to the devolution of the property (other than land) of a person on his death it should be determined according to his personal law.

Rule 6. Subject to the foregoing rules, an issue should be determined according to the common law unless the plaintiff is subject to any system of customary law and claims to have the issue determined according to that system, when it should be so determined.

The appearance of clarity and certainty presented by this catalog of rules on the choice of law problem is misleading. The use of the concept of personal law in a legal order based primarily on the concept of territoriality of laws introduces great complexity. Many of the legal norms of Ghana are applicable within the geographic boundaries of the nation. The common law and the general systems of customary 
law are "personal," however, and their application depends on the particular persons involved. Surprisingly the Courts Act is entirely silent as to the criteria by which one's "personal law" is to be determined. Presumably this determination must still be made on the basis of such ethnic factors as determined the jurisdiction of the former Native Courts, that is, is the person of African descent? Is his way of life that of a native community? If so, of what native community is he a member? While the legislative draftsmen were able to avoid the use of the word "native," the concept of personal law seemingly commits the courts to criteria reminiscent of the colonial period in answering the choice of law questions.

It should be observed that the new legislation actually improves the status of the common law, that is, law derived primarily from England, in its competition with indigenous legal norms. Formerly there was a presumption favoring the applicability of customary law in cases where the parties were "natives" or "of African descent." Customary law might also control in certain cases even though some of the parties were non-natives. Under the new legislation, the initial presumption favors the application of the common law in many instances where previously a contrary presumption would have prevailed. The first five rules specify bases for determining the applicability of "personal law." In these rules "personal law" seemingly is to be taken to mean the common law unless the person affected shows that he is subject to some body of customary law that provides an applicable rule. ${ }^{87}$ This view appears to be confirmed by rule six which declares that "subject to the foregoing rules, an issue should be determined according to the common law unless the plaintiff is subject to any system of customary law and claims to have the issue determined according to that system, when it should be so determined." Thus none of the six rules on the application of "personal law" compels the court on its own initiative to seek out a basis for applying customary law. The court is entitled to apply the common law, unless the affected party establishes the propriety of applying a personal law from the indigenous systems.

A difference in the phraseology of rule six from that employed in the first five rules suggests a further limitation on the application of native custom as personal law. Rules one to five deal with the law applicable in certain property transactions and in cases where the parties have agreed, either expressly or by implication, that a certain law should apply. Within the scope of these rules, either party apparently may claim the benefit of the appropriate personal law and establish the basis for its application. In the residue of cases, covered by rule six, the literal language seemingly would entitle only the plaintiff to negative the presumption of applicability of the common law. Why the important issue of choice of law should be thus determined by the vagaries of the lineup of parties in an action is by no means clear. In any event, it appears that the earlier boundaries between the English-derived common law

${ }^{87}$ Section $66(I)$ of the Courts Act thus declares that in the several specific rules "references to the personal law of a person are references to the system of customary law to which he is subject or, if he is not shown to be subject to customary law, are references to the common law. ..." 
and customary law have been shifted and the area of the indigenous systems restricted.

One final limitation ${ }^{88}$ of the new Courts Act on the application of customary law should be noted. Section sixty-six in conclusion provides that notwithstanding the earlier provisions of the section, which in general sought to delimit an area of application for customary law, two sets of legal rules derived from English law shall apply: (I) the rules of private international law, in any proceedings in which an issue concerning the application of law prevailing in any country outside Ghana is raised; (2) "the rules of estoppel and such other of the rules generally known as the common law and the rules generally known as the doctrines of equity as have heretofore been treated as applicable in all proceedings in Ghana shall continue to be so treated."

The first of these categories is not of primary interest here. The use of conflicts rules derived from English or other non-African law in those cases involving an issue of non-Ghanaian law would affect only a thin stratum of Ghanaian society, primarily those persons engaged in some way in international business transactions. The second category of rules is of greater general interest. The underlying premise is that in pre-Republican Ghana and the Gold Coast, certain rules derived from English common law and equity were applicable in all legal proceedings, even those otherwise governed by the indigenous customary law. All such rules are to be retained in the new legal order. What are these rules and doctrines? The statute provides only one illustration: the rules of estoppel. In general, it may be said that these rules represent particularizations by the courts of the general ideas of "natural justice, equity and good conscience" which in the old legal order set bounds to the application of customary law and also provided the basis for decision where the customary law was thought not to offer a relevant rule.

\footnotetext{
${ }^{88}$ A further inroad on the area of application of customary law was introduced by the Courts Act of 1960 as originally enacted. As already noted, the new Interpretation Act, $\$ I_{7}(I)$, suggested the possibility of a later enactment to provide for the assimilation by the common law of certain rules of customary law found suitable for general application. The Courts Act, $\$ 66(2)$, provided that where, under any of the six rules previously discussed, customary law was applicable but a relevant rule of customary law had been assimilated by the common law, the rule thus assimilated should be applied. The effect of this provision in further curtailing the customary law may be illustrated by the following case. In Fanti law intestate succession to property is matrilineal, while the basic rule among the Ga people provides for patrilineal succession. Assume that under some legislative authorization it were determined that the $\mathrm{Ga}$ rule was more in keeping with the modern economic and social conditions of Ghana and should be assimilated by the common law. In a subsequent case between Fantis involving Fanti lands, the rules of $\$ 66$ of the new Courts Act would indicate that the case should be determined by Fanti customary law. However, since a "relevant" rule, that is, a rule dealing with the kind of problem presented, had been assimilated, the rule assimilated by the common law from the Ga custom would be applicable. To insist that this is still the application of "customary law" is to permit a label to blind one to substance. In so far as the Fanti parties are concerned, their custom would have been rejected in favor of a national rule. Arguably, it would in the circumstances mean no more to them that the national rule was a generalization from an African ( $\mathrm{Ga}$ ) custom than if it were derived from English law. In view of jealousies and historic differences among the indigenous people of Ghana, the nationalization of one tribal rule might be less acceptable than similar treatment of an English doctrine.

This troublesome aspect of the Courts Act has now been eliminated. Section 66(2) of the Courts Act was repealed by $\S 69(I)$ of the Chieftaincy Act, Act 81 of $196 r$.
} 
In summary, it appears clear that the new legal order has not in any way enlarged the scope of application of customary law. On the contrary, in the competition between customary law and English law (common law, equity, and statutes of general application), English law seems somewhat advantaged by the new ordering. This treatment of customary law must be viewed in the larger perspective of the relations between the traditional tribal institutions and the power centers of a new national state. In the new order, the center of activity in creation and adaptation of norms will not be the judiciary administering an amorphous, pluralistic system of customary and common law, but rather the national legislature.

One further feature of the 1960 legislation must be examined. This deals with the determination of the content of customary law in cases governed by it. The earlier view regarded customary law as a matter of fact, at least in the superior courts, to be established by proof. The dictum of Angu $v$. Attah $h^{80}$ had suggested that some rules might become sufficiently "notorious" through frequent proof that judicial notice might be taken of them, but this suggestion does not seem to have been followed. Section $67(\mathrm{I})$ of the Courts Act, I960, declares, however, that the question of the existence or content of a rule of customary law is a question of law for the court and not a question of fact. The important aspect of this provision is not the clear assignment of the finding function to the court rather than to assessors or jury. Even when customary law was deemed a matter of fact, the function of finding it was assigned to the court. ${ }^{90}$ The significant change is that customary law is to be found as law rather than as fact. If the normal consequences of this categorization are to prevail here, a court may determine the applicable customary law rule from its own knowledge or assumed knowledge or from investigations conducted by the court but in no way reflected in the record short of the court's announcement of the rule to be applied.

While freeing the courts from the necessity of building a record to support their findings of customary law, Parliament realistically recognized that in many instances alleged to be controlled by customary law the courts will need to inquire concerning the existence and content of the applicable norm. Under the Courts Act, section $67(2)(3)$, the extent and methods of inquiry are left largely to the court's discretion. Techniques suggested by the statute include considering such "submissions" as may ibe made by the parties, consulting reported cases, textbooks and such "other sources as may be appropriate," calling and hearing such witnesses as the court deems proper, and requesting a written opinion from a House of Chiefs, State Council, "or other body possessing knowledge of the customary law in question." It seems obvious that a court has discretion to determine which one or more of these techniques will be used.

It appears equally obvious that the court is not bound to accept any particular opinion. The statute is silent, however, as to whether a court that has decided to hear witnesses or to request written opinions on the customary law must preserve the

${ }^{80}$ See note 68 supra.

${ }^{\circ 0}$ See Allott, supra note 73, at 248. 
testimony and documents in the record for use by a reviewing court. No such necessity would seem to exist if customary law is indeed to be found as law and if the testimony and opinions of witnesses and the submissions of the parties are analogized to the legal memoranda or oral arguments on the law adduced in a trial court in England or the United States. Whether or not the trial court's inquiry into customary law is preserved in the record, it would appear that any reviewing court may utilize the same techniques for supplementing its assumed knowledge of customary law. A further consequence of the categorization of customary law as law would therefore be that a trial court's determination of the applicable rule would enjoy no presumption of accuracy or reliability on appeal or other review.

Experience alone will determine the actual effect of the new provisions on the finding of customary law. The initial analysis suggests the possibility that in operation they may slowly erode variable local customs in favor of a national "customary law." The similarity between the possible, clearly authorized handling of customary law in the courts of Ghana and the development of the common law in England is striking. To Blackstone the common law of England rested in general custom, but it was known and its validity determined by the judges, "the depositories of the laws; the living oracles, who must decide in all cases of doubt...."91 Local custom, variable throughout the realm, could indeed be given effect subject to rather stringent criteria, but, when relied on, allegation and proof were in general required and the issue thus raised was ordinarily for the jury. ${ }^{92}$ Thus the treatment of customary law under the new Courts Act of Ghana more closely resembles that of general common law in England than local custom. The commitment of the decisional function to the courts as on questions of law augurs the demise of local particularity and the emergence of a body of national Ghanaian common law.

\section{Conclusion}

To a considerable extent the actual impact of the formal changes in the structure of the operative legal norms of Ghana remains speculative. Continuing study of legislative developments and the judicial process is essential. It may be suggested, however, that the grant of independence and the adoption of a Republican form of government have not served to revitalize that part of the legal order which is derived from the indigenous societies. On the contrary, this component of the legal order seems to have suffered continued attrition in favor of legal institutions and legal norms received from non-indigenous, primarily British sources and incorporated in a rapidly growing body of national legislation. 93 In so far as "Africanization" of

-1 I William Blackstone, Commentaries on the Laws of England *69 (3d ed. i892).

92 Id. at " $74-76$.

as Following the creation of the Republic a comprehensive scheme of statute law revision was begun under the general direction of the Attorney-General by a Parliamentary Draftsman on loan from the Government of Ireland with the aid of some members of the Attorney-General's staff. The purpose of the scheme was to replace all pre-July, I960, statute law by a series of consolidating enactments in modern language. Among the statutes thus far produced are the Legal Profession Act, Arbitration Act, 
the legal order is to occur, it is to be expected mainly from the activity of Parliament. The extent to which legislative reforms draw inspiration from indigenous institutions or remain more broadly eclectic can only be determined by analysis, too detailed for this paper, of enactments since independence.

Extradition Act, Judgments (International Enforcement) Act, Criminal Code, Criminal Procedure Code, Lotteries and Betting Act, Coroners Act, Notaries Public Act, Administration of Estates Act, Apprentices Act, Bills of Exchange Act, Bills of Lading Act, and Contracts Act. A major study has also been made by Professor L. C. B. Gower of the London School of Economics looking toward a comprehensive revision of the company law of Ghana. Commission of ENQuiRy INTo tHE Workung AND ADMinistrution of the Present Company Law of Ghana, Accra, finat Report (Ig6i). 